\title{
Influence of the colon in liver regeneration of rats submitted to hepatectomy and colectomy
}

\section{Influência do cólon na regeneração do fígado de ratos submetidos à hepatectomia e colectomia}

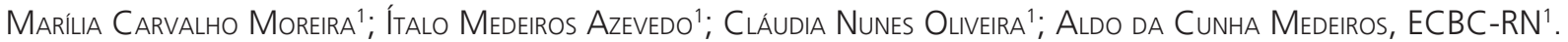

\begin{abstract}
A B S T R A C T
Objective: to evaluate whether colectomy, associated with 70\% hepatectomy, influences liver regeneration in rats. Methods: we distributed 18 Wistar rats in three groups of six animals each. In group I (sham), we performed laparotomy; In group II, colectomy + 70\% hepatectomy; In group III, only 70\% hepatectomy. On the 6th postoperative day, we collected blood by cardiac puncture under anesthesia, followed by euthanasia. We performed serum dosages of aspartate aminotransferase (AST), alanine aminotransferase (ALT), albumin and alkaline phosphatase (AF), hepatocyte growth factor (HGF) and transforming growth factor- $\alpha$ (TGF- $\alpha$ ). We calculated liver regeneration by the formula: liver weight ratio per $100 \mathrm{~g}$ body weight at the time of euthanasia / liver weight preoperatively projected for $100 \mathrm{~g}$ body weight $\times$ 100. Results: ALT and AST levels were significantly lower in group II when compared with group III (p<0.001). Albuminemia showed significantly higher levels in group II. Levels of HGF and TGF- in group II were significantly higher than in group III. The percentage of hepatic regeneration was significantly higher in group II than in group III. Conclusion: Colectomy performed simultaneously with $70 \%$ hepatectomy had a positive influence on liver regeneration in rats. Further research is needed to reveal the molecular mechanisms of this effect and to characterize the colon influence in liver physiology.
\end{abstract}

Keywords: Liver Regeneration. Colectomy. Hepatectomy. Rats.

\section{INTRODUCTION}

$\mathrm{T}$ he liver is one of the most complex organs in the human body. Its mass is measured in proportion to the individuals' body weight ${ }^{1}$, and this ratio is restored after hepatic resection ${ }^{2}$. Half of all patients with colorectal cancer develop hepatic metastases in the course of this disease ${ }^{3}$. Patients with metastases may benefit from hepatic resection, as it provides an opportunity for healing ${ }^{4}$, with isolated segmentectomy and lobectomy being the most common surgical interventions. The results have been relatively good if the resection safety margins and the liver functional reserve are adequate ${ }^{5}$. Long-term survival after liver resection for colorectal metastases has improved significantly in recent years ${ }^{6}$. These facts justify the study of hepatic regeneration in the presence of simultaneous colectomy, due to the high incidence of colorectal disease with metastases and to the frequency with which these procedures are performed at the same operative time.

Liver regeneration has been the subject of studies over the years. However, the mechanisms by which the organ is stimulated to replicate and the relationship between cells and cytokines have not yet been fully elucidated. Nutritional and other factors have been evaluated, all demonstrating some influence on the regeneration process ${ }^{7-9}$. New knowledge has emerged on liver regeneration, emphasizing the performance of growth factors and other cytokines ${ }^{10,11}$. In animal models, hepatic regeneration mechanisms have been investigated in detail. Hepatocytes early express tumor necrosis factor- $\alpha$ (TNF- $\alpha$ ) and interleukin- 6 (IL-6), mainly produced by Kupffer cells, and the proliferation and growth of hepatocytes are induced primarily in response to the transforming growth factor- $\alpha$ (TGF- $\alpha$ ) and hepatocyte growth factor (HGF), among others $^{10}$.

One of the first studies to investigate the coIon role in hepatic regeneration examined the effect of ileocolectomy associated with 50\% hepatectomy on the regenerative response, evaluating thymidine kinase activity and mitotic figures as regeneration markers.

1 - Federal University of Rio Grande do Norte, Post-graduation Program in Health Sciences, Natal, RN, Brazil. 
When compared, this surgical procedure generated a significantly greater regenerative response than sole hepatectomy or hepatectomy with ileum resection ${ }^{12}$. Moser et al. ${ }^{13}$ studied the participation of genetic factors in hepatic regeneration after colectomy in 2006. However, a study by Hachiya et al. ${ }^{14}$ in 2008 concluded that the process of liver regeneration after synchronous resection of the liver and colon in rats was reduced.

Faced with the controversy, we seek to contribute to the theme. The objective of the present study was to examine the influence of extensive colon resection on liver function and regeneration in an experimental rat model.

\section{METHODS}

The Institutional Committee on Ethics in the Use of Animals approved the research project under protocol number 054-10. The animal care followed the standards of the Brazilian legislation for the scientific use of animals (Law 11.794/2008, CONCEA).

We used 18 male, adult Wistar rats (Rattus norvegicus), weighing $294 \pm 13 \mathrm{~g}$, supplied by the Health Center of the Federal University of Rio Grande do Norte (UFRN). The animals were housed in individual polypropylene cages with 12-hour light-dark cycles, controlled humidity and temperature, with ad libitum access to water and chow for rodents. For seven days prior to the experiment, they remained in the laboratory for acclimatization. One day before the surgical interventions, they took only water, and were then randomly divided into three groups with six rats each: in group I (sham), we performed laparotomy; in group II, colectomy $+70 \%$ hepatectomy; in group III, only $70 \%$ hepatectomy. All animals were anesthetized with intraperitoneal injection of ketamine $(70 \mathrm{mg} / \mathrm{kg}$ ) and xylazine $(10 \mathrm{mg} / \mathrm{kg})$, and operated with aseptic technique after abdominal wall trichotomy and antisepsis with $70 \%$ ethyl alcohol.

The animals of group II, 70\% hepatectomy + colectomy, underwent median laparotomy, through which we resected the whole cecum and $5 \mathrm{~cm}$ of the proximal colon, proceeding with an end-to-end, sin- gle-plane ileocolic anastomosis, with simple, separated stitches of 60 polypropylene, with the aid of a DFV surgical microscope (São Paulo, Brazil), 10x magnification. Concomitantly, we resected the left and middle lobes of the liver (70\% hepatectomy). In group III, hepatectomy, the animals were submitted to resection of the left and middle lobes of the liver (70\% hepatectomy). In the sham group, we carried out a median laparotomy and mild manipulation of the cecum and liver under the same conditions of anesthesia and antisepsis. In all animals, after checking hemostasis, we sutured the abdominal incision in two planes with 4-0 nylon sutures. After the intervention, postoperative pain control was done with intramuscular meperidine at a dose of $10 \mathrm{mg} / \mathrm{kg}$ once daily for the first three days. We kept the animals under observation for six days, during which we observed weight loss parameters through digital weighing, with sensitivity to variation of one gram.

The animals received only water in the first 24 postoperative hours, followed by a solid diet until euthanasia and, in the observation period, were kept in a postoperative control room. On the sixth postoperative day, we weighed and anesthetized the animals with the same technique described above, and collected $5 \mathrm{ml}$ blood samples by cardiac puncture for laboratory tests. We then submitted them to euthanasia with an anesthetic overdose $(100 \mathrm{mg} / \mathrm{Kg}$ intraperitoneal thiopental sodium). We resected the remaining liver (right lobe), washed it with $0.9 \%$ saline solution and weighed it on a precision scale. In the sham group, we weighed the whole liver.

\section{Serum dosages}

We processed the whole blood serum collected from the animals on the sixth postoperative day by centrifugation at 3,000 rpm for ten minutes, and stored it at $40^{\circ} \mathrm{C}$ until dosed. We measured serum levels of aspartate aminotransferase (AST), alanine aminotransferase (ALT), albumin and alkaline phosphatase $(A F)$ in all animals with Wiener kits, Konelab Autoanalyzer, Finland. We used Enzyme-linked immunosorbent assays (ELISA) for the determination of hepatocyte growth factor (HGF) and transforming growth factor- $\alpha$ (TGF- $\alpha$ ), using ABCAM kits (Massachusetts, USA) and a microplate reader (BioTek, Vermont USA). 


\section{Calculation of hepatic regeneration}

Initially, we calculated the hepatic mass / body mass ratio of sham animals (HMBMR). After the observation period, we weighed the rats (B) in a precision scale, removed the entire liver and weighed it too (A). We expressed the acquired data as a percentage of the ratio of $A$ to $B$, multiplied by 100 , calculated by the formula: $\mathrm{HMBMR}=$ (Liver mass / Body mass) $\times 100$.

This ratio established the percentage that the liver represents over the body mass of each animal. We evaluated the changes in the HMBMR of the animals of the studied groups as degree of hepatic regeneration. Hepatic Regeneration (HR) was defined as: $\mathrm{HR}=([\mathrm{HMB}-$ MReuta - HMBMRpos] / HMBMRpos) x 100. Where: HR is the percentage of hepatic regeneration; HMBMReuta is the Hepatic Mass-Body Mass Ratio in euthanasia (after the observation period); HMBMRpos is the Hepatic Mass-Body Mass Ratio in the immediate postoperative period (shortly after hepatectomy).

\section{Statistical analysis}

We used the ANOVA test followed by the Tukey test to compare the laboratory parameters be- tween groups. To evaluate the difference between the means of liver regeneration between groups, we applied the Student's t-test. For all tests, we set the significance level at 5\%, using the statistical package SPSS 21 .

\section{RESULTS}

All animals survived the experiments and there was no significant difference in the evolution of their body weights between groups. On the 6th postoperative day, biochemical measurements showed significantly higher levels of ALT in animals submitted to $70 \%$ hepatectomy + colectomy when compared with the sham group $(p<0.01)$. However, ALT, AST and AF levels in the group of animals submitted solely to hepatectomy were significantly higher than in the hepatectomy + colectomy group $(p<0.01)$. Albuminemia was significantly higher in the rats of the sham and hepatectomy + colectomy groups than in the hepatectomy group $(p<0.01)$. There was no significant difference of albuminlevels between the sham and the hepatectomy + colectomy groups ( $p>0.05)$. Table 1 summarized the values of the biochemical data.

Table 1. Values of biochemical data and their statistical interpretation.

\begin{tabular}{lccc}
\hline & Sham & $70 \%$ Hepatectomy + colectomy & $70 \%$ Hepatectomy \\
\hline ALT (IU/l) & $46.6 \pm 3.01^{\mathrm{a}}$ & $128.7 \pm 5.1^{\mathrm{a}}$ & $208.4 \pm 19.3^{\mathrm{a}}$ \\
$\mathrm{AST}(\mathrm{IU} / \mathrm{l})$ & $50.05 \pm 2.17^{\mathrm{a}}$ & $49.1 \pm 2.04^{\mathrm{b}}$ & $69.7 \pm 2.7^{\mathrm{ab}}$ \\
$\mathrm{AF}(\mathrm{IU} / \mathrm{l})$ & $154.6 \pm 15.3^{\mathrm{a}}$ & $161.5 \pm 6.1^{\mathrm{b}}$ & $211.6 \pm 13.7^{\mathrm{ab}}$ \\
Albumin $(\mathrm{g} / \mathrm{l})$ & $4.6 \pm 0.4^{\mathrm{a}}$ & $4.1 \pm 0.2^{\mathrm{b}}$ & $3.4 \pm 0.3^{\mathrm{ab}}$
\end{tabular}

Tukey test: mean $\pm S D$ values followed by the same letter are statistically significant, with $p<0.01$. AST, Aspartate aminotransferase; ALT, Alanine aminotransferase; AF, Alkaline Phosphatase.

Table 2 shows that the values of the HGF and TGF $\alpha$ of the animals submitted to hepatectomy + colectomy were significantly higher than in the sham and hepatectomy groups $(p<0.01)$.

The calculation of the percentage of hepa- tic regeneration revealed that in the animals of the hepatectomy + colectomygroup, regeneration occurred significantly higher than in the animals submitted to isolated hepatectomy $(p=0.003)$. These data are summarized in table 3 . 
Table 2. Values of growth factors and their statistical interpretation.

\begin{tabular}{lccc}
\hline & Sham & $70 \%$ Hepatectomy + colectomy & $70 \%$ Hepatectomy \\
\hline HGF $(\mathrm{pg} / \mathrm{ml})$ & $282.8 \pm 13.3^{\mathrm{a}}$ & $408 \pm 18.2^{\mathrm{a}}$ & $360 \pm 58.6^{\mathrm{a}}$ \\
\hline $\mathrm{TGF}-\alpha(\mathrm{ng} / \mathrm{ml})$ & $0.93 \pm 0.1^{\mathrm{a}}$ & $3.8 \pm 0.3^{\mathrm{a}}$ & $2.3 \pm 0.4^{\mathrm{a}}$ \\
\hline
\end{tabular}

Tukey test: mean $\pm S D$ values followed by the same letter are statistically significant, with $p<0.01$.

Table 3. Descriptive data and inferential test of liver regeneration.

\begin{tabular}{lccc} 
& \multicolumn{2}{c}{ Groups } & \\
\cline { 2 - 3 } & $\begin{array}{c}70 \% \\
\text { Hepatectomy }\end{array}$ & $70 \%$ Hepatectomy + colectomy & p-value \\
\hline Regeneration (\%) & $18.8 \pm 8.90$ & $52.7 \pm 16.32$ & 0.003 \\
\hline
\end{tabular}

Mean \pm standard deviation (Student's $t$ test).

\section{DISCUSSION}

Hepatic regeneration is a very complex topic that arouses great interest due to the way it happens through cellular interactions, humoral and molecular mechanisms, and influence of portal system organs, which have not yet been fully elucidated. In a previous study, we demonstrated that the ileus acts positively on the parameters of hepatic regeneration in rats ${ }^{15}$.

The present study showed that animals submitted to $70 \%$ hepatectomy simultaneous to a resection of the cecum and part of the colon had significantly better hepatic regeneration during the observation period than animals submitted to $70 \%$ hepatectomy alone. The hepatic resection simultaneous to colectomy did not increase the risk of postoperative complications and all rats survived until the end of the experiments. Our results suggest that simultaneous colon and liver resection contributed to improve hepatic regeneration parameters assessed on the sixth postoperative day and, at the same time, liver function and injury tests had more favorable levels than in animals with isolated hepatectomy. Hachiya et al. ${ }^{14}$ performed an ileocolectomy simultaneously with hepatectomy in rats and concluded that there was a reduction in regeneration and impairment of endothelial cell function in the remaining liver. One criticism to their model is that they added ileus resection to the animals.
It is known that ileus is essential to the process of liver regeneration ${ }^{15}$. A study in rats submitted to hepatectomy and simultaneous resection of a segment of only $1 \mathrm{~cm}$ of the colon concluded that there was a higher degree of liver regeneration than in the animals submitted to isolated hepatectomy ${ }^{16}$. The theme is controversial, the studies are scarce in the literature and the methodology is much varied.

We indirectly analyzed the degree of hepatic impairment due to injury caused by interventions in the liver and colon, through ALT, AST, AF and albumin. Being a cytoplasmic and mitochondrial enzyme, AST is found in many organs besides the liver, including heart, skeletal muscle, kidneys and brain tissues. However, ALT is cytoplasmic, is mainly found in the liver and is more specific than $\mathrm{AST}^{17}$. Serum transaminases are sensitive in the demonstration of hepatocyte damage and, independent of etiological factors, their values remain high while hepatic lesions persist ${ }^{17}$. Table 1 show that ALT levels were higher in the hepatectomy + colectomy group compared with sham, and this serum level was significantly lower than in the isolated hepatectomy group. As regards to AST, AF and albumin, their serum levels did not differ significantly between the hepatectomy + colectomy and sham groups. These data are relevant because they may mean that the absence of the colon should have exerted a protective effect on the liver and had a positive influence on 
liver regeneration.

In order to calculate the percentage of hepatic regeneration, we chose to compare only the two groups with hepatectomy, since in the sham group, there was no intervention in the liver and we considered liver regeneration null.

There are many growth factors produced by hepatocytes during regeneration ${ }^{18}$. TGF- $\alpha$ has been shown to be mitogenic for hepatocytes in cultures, being more active than other growth factors, which are mitogenic for various types of non-parenchymal cells, especially endothelial cells. TGF- $\alpha$-deficient mice have a normal hepatic regeneration after hepatectomy ${ }^{19}$. HGF is a potent hepa- tocyte proliferation factor ${ }^{10}$. In the present study, the association of colectomy with hepatectomy had a positive relationship with serum levels of HGF and TGF- $\alpha$ on the sixth postoperative day, coinciding with a higher percentage of hepatic regeneration than in the group of animals submitted to isolated hepatectomy. These findings are consistent with findings of other authors ${ }^{20}$.

Our study demonstrated that colectomy positively influenced liver regeneration after 70\% hepatectomy in rats. Further research is needed to reveal the molecular mechanisms of this effect and to characterize the influence of the colon on other parameters of liver physiology.

\title{
R E S U M O
}

\begin{abstract}
Objetivo: avaliar se a colectomia, associada à hepatectomia 70\%, influencia a regeneração do fígado em ratos. Métodos: foram utilizados 18 ratos Wistar distribuídos em três grupos de seis animais cada. No grupo I (sham) foi realizada laparotomia; no grupo II colectomia + hepatectomia 70\%; no grupo III apenas hepatectomia 70\%. No sexto dia pós-operatório foi colhido sangue por punção cardíaca, sob anestesia, seguido de eutanásia. Foram realizadas dosagens séricas de aspartato aminotransferase (AST), alanina aminotransferase (ALT), albumina e fosfatase alcalina (FA), fator de crescimento de hepatócitos (HGF) e fator de crescimento transformador- $\alpha$ (TGF- $\alpha$ ). A regeneração do fígado foi calculada pela fórmula: razão peso do fígado por $100 \mathrm{~g}$ do peso corporal no momento da eutanásia/peso do fígado no pré-operatório projetado por $100 \mathrm{~g}$ de peso corporal $\times 100$. Resultados: Os níveis de ALT e AST foram significativamente menores no grupo II quando comparados com o grupo III $(p<0,001)$. A albuminemia mostrou níveis significativamente mais elevados no grupo II. Os níveis de HGF e TGF-a no grupo II foram significativamente mais elevados que no grupo III. O percentual de regeneração hepática foi significativamente mais elevado no grupo II do que no grupo III. Conclusão: o estudo demonstrou que a colectomia realizada simultaneamente à hepatectomia $70 \%$ influenciou positivamente na regeneração do fígado em ratos. Pesquisas adicionais são necessárias para revelar os mecanismos moleculares deste efeito e para caracterizar a influência do cólon na fisiologia do fígado.
\end{abstract}

Descritores: Regeneração Hepática. Colectomia. Hepatectomia. Ratos.

\section{REFERENCES}

1. Tarlás MR, Ramalho FS, Ramalho LNZ, Castro-e-Silva T, Brandão DF, Ferreira J, et al. Cellular aspects of liver regeneration. Acta Cir Bras. 2006;21(Suppl. 1):63-6

2. Fausto N. Liver regeneration. J Hepatol. 2000;32(Suppl. 1):19-31.

3. Faivre J, Manfredi S, Bouvier AM. [Epidemiology of colorectal cancer liver metastases]. Bull Acad Natl Med. 2003;187(5):815-22. French.

4. Wicherts DA, Miller R, de Haas RJ, Bitsakou G, Vibert $E$, Veilhan $L A$, et al. Long-term results of two-stage hepatectomy for irresectable colorectal cancer liver metastases. Ann Surg. 2008;248(6):994-1005.

5. Inoue Y, Hayashi M, Komeda K, Masubuchi S, Yamamoto $\mathrm{M}$, Yamana $\mathrm{H}$, et al. Resection margin with anatomic or nonanatomic hepatectomy for liver metastasis from colorectal cancer. J Gastrointest Surg. 2012;16(6):1171-80.

6. Tomlinson JS, Jarnajin WR, DeMatteo RP, Fong $Y$, Kornprat P, Gonen M, et al. Actual 10-year survival after resection of colorectal liver metastases defines cure. J Clin Oncol. 2007;25(29):4575-80.

7. Silva RM, Malafaia O, Torres OJ, Czeczko NG, Marinho Jr CH, Kozlowski RK. Evaluation of liver regeneration diet supplemented with omega-3 fatty acids: experimental study in rats. Rev Col Bras Cir. 2015;42(6):393-7.

8. Toderke EL, Baretta GAP, Gama Filho OP, Matias JEF. Sirolimus influence on hepatectomy-induced liver regeneration in rats. Rev Col Bras Cir. 2014;41(3):203-7.

9. Salomão LS, Young SB, Galhardo MA, Pereira LA, Pires AR, Boaventura GT, et al. Evaluation of liver regeneration by modulation with ischemic 
preconditioning after ischemia and reperfusion and partial hepatectomy. Rev Col Bras Cir. 2012;39(3):211-5.

10. Fausto N, Campbell JS, Riehle KJ. Liver regeneration. Hepatology. 2006;43(2 Suppl 1):\$45-53.

11. Jesus RP, Waitzberg DL, Campos FG. Regeneração hepática: papel dos fatores de crescimento e nutrientes. Rev Assoc Med Bras. 2000;46(3):242-54.

12. Kahn D, Von Sommoggy S, Hickman R, Terblanche $J$. lleocolectomy enhances the regenerative response after partial hepatectomy in the pig. S Afr J Surg. 1990;28(1):11-3.

13. Moser MJ, Gong Y, Zhang MN, Lipschitz J, Cohen A, Minuk GY. The effects of colectomy on immediateearly proto-oncogene expression and hepatic regeneration in the rat. Dig Dis Sci. 2006;51(7):117982.

14. Hachiya $Y$, Chijiiwa $K$, Noshiro $H$, Tanaka $M$. Impaired liver regeneration after synchronous liver and colon resection in rats. Hepatogastroenterology. 2008;55(82-83):641-6.

15. Medeiros AC, Azevedo AC, Oséas JM, Gomes MD, Oliveira FG, Rocha $K B$, et al. The ileum positively regulates hepatic regeneration in rats. Acta Cir Bras. 2014;29(2):93-8.

16. Sasanuma $H$, Mortensen FV, Knudsen AR, FunchJensen $\mathrm{P}$, Okada $\mathrm{M}$, Nagai $\mathrm{H}$, et al. Increased liver regeneration rate and decreased liver function after synchronous liver and colon resection in rats. Ann
Surg Innov Res. 2009;3(1):1-7.

17. McGill MR. The past and present of serum aminotransferases and the future of liver injury biomarkers. EXCLI J. 2016;15(6):817-28.

18. Matsumoto K, Miyake $Y$, Umeda $Y$, Matsushita H, Matsuda $H$, Takaki A, et al. Serial changes of serum growth fator levels and liver regeneration after partial hepatectomy in healthy humans. Int J Mol Sci. 2013;14(10):20877-89.

19. Russell WE, Kaufmann WK, Sitaric S, Luetteke NC, Lee DC. Liver regeneration and hepatocarcinogenesis in transforming growth factor-alpha-targeted mice. Mol Carcinog. 1996;15(3):183-9.

20. Efimova EA, Glanemann M, Nussler AK, Schumacher $G$, Settmacher $U$, Jonas $S$, et al. Changes in serum levels of growth factors in healthy individuals after living related liver donation. Transplant Proc. 2005;37(2):1074-5.

Received in: 24/04/2017

Accepted for publication: 01/06/2017

Conflict of interest: none.

Source of funding: National Council for Scientific and Technological Development, Protocol No. 4449083 / 20144.

\section{Mailing address:}

Marília Carvalho Moreira

E-mail: mariliarn@gmail.com / cirurgex.ufrn@gmail.com 